\title{
Promoting Sustainable Mobility: Impact of an Urban Biking Programme on University Students
}

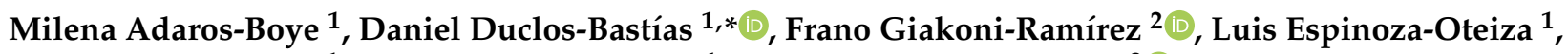 \\ Carolina Cid-Robles ${ }^{1}$, Jorge Gálvez-Carvajal. ${ }^{1}$ and Carlos Matus-Castillo ${ }^{3}$ (D) \\ 1 School of Physical Education, Pontificia Universidad Católica de Valparaíso, Valparaíso 2374631, Chile; \\ milena.adaros@pucv.cl (M.A.-B.); luis.espinoza@pucv.cl (L.E.-O.); carolina.cid@pucv.cl (C.C.-R.); \\ jorge.galvez@pucv.cl (J.G.-C.) \\ 2 Faculty of Education, Universidad Autónoma de Chile, Temuco 4810101, Chile; frano.giakoni@uautonoma.cl \\ 3 Department of Sports Sciences and Physical Conditioning, Universidad Católica de la Santísima Concepción, \\ Concepción 4090541, Chile; cmatus@ucsc.cl \\ * Correspondence: daniel.duclos@pucv.cl
}

Citation: Adaros-Boye, M.;

Duclos-Bastías, D.; Giakoni-Ramírez,

F.; Espinoza-Oteiza, L.; Cid-Robles, C.;

Gálvez-Carvajal., J.; Matus-Castillo, C.

Promoting Sustainable Mobility:

Impact of an Urban Biking

Programme on University Students.

Sustainability 2021, 13, 12546.

https://doi.org/10.3390/su132212546

Academic Editors: Ma Luisa

Zagalaz Sánchez,

Javier Cachón-Zagalaz, María

Sánchez Zafra, Déborah

Sanabrias Moreno and Jordi

Colomer Feliu

Received: 9 September 2021

Accepted: 10 November 2021

Published: 13 November 2021

Publisher's Note: MDPI stays neutral with regard to jurisdictional claims in published maps and institutional affiliations.

Copyright: (C) 2021 by the authors. Licensee MDPI, Basel, Switzerland. This article is an open access article distributed under the terms and conditions of the Creative Commons Attribution (CC BY) license (https:/ / creativecommons.org/licenses/by/ $4.0 /)$.

\begin{abstract}
The use of bicycles is an active and sustainable mode of transport par excellence. It is a way of increasing people's physical activity time and should therefore be promoted in educational contexts. The aim of this research was to evaluate the effectiveness of an urban bicycle programme in a sample of 164 university students $(n=164), 88$ women and 76 men, using a standardised instrument with pre and post measures after a theoretical-practical intervention. The sample was divided into an intervention group $(n=122)$ with 69 women and 53 men; and control group $(n=42)$ with 19 women and 23 men. The instrument considered conceptual and attitudinal aspects. The results showed that participants in the intervention group obtained statistically significant improvements $(p \leq 0.05)$ in the measurement. No significant improvements were observed in the control group $(p=0.35)$, which means that the urban intervention programme is an effective method for increasing bicycling knowledge and attitudes in the university students who participated in the experience.
\end{abstract}

Keywords: urban biking; physical activity; safety; university students; intervention

\section{Introduction}

An active life is directly related to regular physical activity (PA), which is a relevant activity that contributes to the development of society, due to its impact on human development, from a physical, social, inclusive, and economic dimension, becoming an important element in people's lives [1,2]. This has earned it consideration in the Sustainable Development Goals and its contribution, mainly in the goals: "Health and well-being", "Gender equality", "Sustainable Cities and Communities" and "Climate Action" promoted by the United Nations [3]. Sustainability, therefore, has positioned itself as a feature increasingly present in organisations promoting physical activities and sports [4].

From a health perspective, regular PA is a fundamental metabolic and cardiovascular protective factor in people's health [5,6]. For this reason, international organisations recommend a minimum level of 150 min per week of moderate intensity, 75 min per week of vigorous intensity [7], or 10,000 steps per day [8]. In contrast, physical inactivity (PI) combined with a sedentary lifestyle decreases people's health status [9]. As a consequence, it has become evident that a large percentage of people are at risk of developing chronic non-communicable diseases, due to a sustained increase in PI levels worldwide [10,11].

\subsection{University, Physical Activity and Sustainability}

In relation to the university context and sustainability, it is important to note that the United Nations declared the period 2005-2014 as the "Decade of Education for Sustainable 
Development" [12] and the United Nations Educational, Scientific and Cultural Organisation proposed to promote the integration of the principles and actions of sustainable development in all dimensions of education [13]. For this reason, it is justified that universities promote healthy and sustainable behaviours in their communities, such as PA. Along these lines, Martínez and García [14] present a classification of sport that makes it possible to identify among them PA and university sport, the purpose of which is to complement the training of students in higher education. This distinction is necessary because their characteristics and beneficiaries are quite specific. Almorza and Prada-Olivera [15] add that the objectives of university sport are to improve health, physical condition, quality of life, and the development of physical qualities and motor skills, as well as be an alternative way of occupying free time, and even a vehicle for establishing social relations. However, it has been shown that young people who begin their university studies do insufficient PA, a prevalence that increases drastically during the transition between adolescence and adults [16]. This implies future risk and consequences on the well-being and health of this population, as well as considerably modifying the practice of physical and sporting activities $[16,17]$.

\subsection{Bicycles as a Sustainable Means of Transport}

Active mobility is an option to add minutes of daily PA by eliminating moments of sedentary activities $[18,19]$. The bicycle has been an important mode of mobility throughout history, even being one of the most widely used before the mass consumption of motor vehicles, which made it possible to reduce travel time, increasing the distances travelled with less physical effort [20].

Current lifestyles encourage people to make decisions that require less time without considering the impact that this may have on health, which has led to an increase in PI and sedentary lifestyles, causing an increase in mortality and morbidity [21]. The active mobility by bicycle favours the body exercise and the increase of daily PA with direct implication on the cyclist's health [18-22]. In this line, evidence was found by Pérez et al. [23] of improvements in physical fitness in bicycle use between home and school. Even regular use provides economic benefits [24], improving aerobic capacity, body composition, the immune system, as well as increasing levels of well-being by reducing stress and increasing serotonin [25]. On the other hand, its efficiency, which reaches average distances of 5-7 km, can become a micromobility option associated with factors such as the feeling of freedom, acceptability, safety and security [26], and a social way of life [27].

However, there are some constraints to bicycle use, which have an effect on many people who have stopped bicycling due to the fear of accidents [18,28-30]. The environmental barrier of fear due to lack of safety (crossings and intersections, the existence or not of bicycle lanes, the recklessness of motor vehicle drivers, among others) is one of the factors that most affects active mobility $[18,21,28,29]$. The "traffic calming" of residential neighbourhoods in more cities and countries is essential to promote cycling and safety [31], as there are multiple benefits to intervening against "trafficking violence" which, according to Carvalho and Freitas [32], is a very important factor in the fight against trafficking violence, which is the biggest cause of death among cyclists.

\subsection{Bicycle Use by University Students}

In relation to the influence of bicycle use in the university population, the 2016-2017 National Health Survey published by the Chilean Ministry of Health indicated that the population of young people aged 15-19 increased their level of sedentary lifestyles compared to 2010 , reaching $73.5 \%$, with $54 \%$ overweight and $27.6 \%$ obese. On the other hand, young people between 20 and 29 years of age have a sedentary lifestyle of $81.2 \%, 37.7 \%$ overweight, and $35.8 \%$ obese [33]; even the group of university students was considered a target population of the National Health Promotion Policy [34]. In this way, it is believed that promoting lifestyle changes in this age range will endure and will be passed on to the institutions in which they will work in the future [35]. However, entering university 
produces a turning point with a progressive decrease in PA practice towards a sedentary lifestyle [36], which coincides with the fact that university students have low or no PA levels and high rates of sedentary lifestyles [30-37]. The reasons are mainly related to the workloads required for a university career, the availability of places to wash up, and the lack of free time [38].

On the other hand, it has been shown that the intervention of urban bicycle programs for university students is an effective method for the promotion and increase of knowledge about road rules for the use of bicycles by this population [39]. For Galvis [40], young university students are aware of the advantages of the use of bicycles, however, few use them, mainly due to lack of information and support, without considering that they also have to travel to different places throughout the day [35]. Therefore, there is a need for universities to promote road safety education in their student community, so that this knowledge has an impact on increasing the use of bicycles as a form of active transport. In this way, levels of sedentary lifestyles will decrease and the time spent on PA will increase, in an informed and, therefore, safer way.

For all of the above reasons, the purpose of this study was to evaluate the implementation of an urban bicycle programme for Chilean university students attending courses in Fundamental Formation of Self-Care and Healthy Lifestyle (SHL), as well as to promote instances of knowledge and use of the bicycle that favour an increase in its use as a means of transport, given that in Chilean reality there is a low level of use of bicycles [41].

\section{Materials and Methods}

\subsection{Sample}

The sampling used was non-probability intentional. The sample analysed consisted of university students $(n=164), 88$ females $(53.7 \%)$ and 76 males $(46.3 \%)$, with an average age of 21.95 years $(\mathrm{SD}=2.53)$. The sample was distributed in two groups as authorised by the university authorities: an Intervention Group $\left(\mathrm{G}_{1} ; n=122\right)$ composed of 69 females $(56.6 \%)$ and 53 males $(43.4 \%)$, and a Control Group $\left(\mathrm{G}_{2} ; n=42\right)$, composed of 19 females $(45.2 \%)$ and 23 males $(54.8 \%)$. The following inclusion criteria were considered for the composition of both groups: a) being a regular student of the Pontificia Universidad Católica de Valparaíso; b) being enrolled in a SHL course; c) having participated in the class that included the theoretical session and the first practical session of the intervention; and d) having answered the pre-test and post-test. Table 1 below presents the socio-demographic characteristics of the total sample and the distribution by groups.

Table 1. Socio-demographic characteristics of the total sample and distribution by groups.

\begin{tabular}{cccc}
\hline & $\begin{array}{c}\text { Total Sample } \\
(\boldsymbol{n}=\mathbf{1 6 4})\end{array}$ & $\mathrm{G}_{\mathbf{1}}(\boldsymbol{n}=\mathbf{1 2 2})$ & $\mathrm{G}_{\mathbf{2}}(\boldsymbol{n}=\mathbf{4 2})$ \\
\hline Age, mean (SD) & $21.95(2.53)$ & $21.93(2.43)$ & $22(2.85)$ \\
\hline Gender, $n(\%)$ & & \\
Female & $88(53.7)$ & $69(56.6)$ & $19(45.2)$ \\
Male & $76(46.3)$ & $53(43.4)$ & $23(54.8)$ \\
\hline Note: SD $=$ Standard deviation; $\mathrm{G}_{1}=$ Intervention group; $\mathrm{G}_{2}=$ Control group.
\end{tabular}

\subsection{Instrument}

To obtain the necessary information about the sample of students, before and after the intervention, an instrument on knowledge of the basic rules of the road and cycle behaviour was applied, designed by López [42], and composed of two dimensions: (i) conceptual dimension: which consists of 13 questions with 3 nominal answer alternatives $(a, b$ or c) based on the recognition of road signs and police signals. (ii) Attitudinal dimension: composed of 12 questions based on cyclist behaviour, including images of situations encountered on the roads, as well as technical aspects, such as the correct use of helmets and other aspects of road safety through dichotomous alternative answers (True and False), image recognition, and fill in the answers; each of the 25 items was marked with 1 
point per correct answer. Previous to its application, the test was subjected to a content validation $[43,44]$ and semantically analysed for application in a variety of contexts with the intention of reducing inappropriate idiomatic interpretations [45], through the judgement of eight experts, all researchers and academics, with more than 5 years of research experience and recent publications indexed in Scopus and WoS in the field of physical activity, quality of life, and sustainable sport. The items of the instrument were validated by Delphi criteria, with three rounds of corrections until approval was obtained [46], which concluded with the development of a pilot test on a small sample of students.

\subsection{Procedure}

The intervention was evaluated through pre and post-test results with an instrument related to cycling knowledge and attitudes. The whole intervention lasted 12 weeks, not including the preparation of the project report. In particular, the intervention sessions with the participants lasted $45 \mathrm{~min}$ each.

In a theoretical session (separately), $G_{1}$ and $G_{2}$ subjects explained the characteristics of the intervention and asked to sign an informed consent form adhering to the Singapore Declaration [47]. Next, the pre-test of the instrument was then applied to all participants $\left(G_{1}\right.$ and $\left.G_{2}\right)$. Once the information was obtained, we proceeded with the implementation of a 30-min theoretical session for $G_{1}$, where a presentation was given on the use of bicycles in urban areas. Subsequently, the first practical intervention was carried out, where participants applied the contents of the theoretical session through a street simulation circuit, adapted to a soccer field within the university. In the following sessions, the $\mathrm{G}_{1}$ intervention continued with practical activities in a real environment and context and went through the streets near the university campus. Once the intervention was completed, the post-test was carried out by repeating the measurement of the data collection instrument for groups $\mathrm{G}_{1}$ and $\mathrm{G}_{2}$.

\section{Intervention}

The first intervention consisted of a theoretical session for the $G_{1}$ group where topics such as the obligations and rights of cyclists according to the Traffic Law, [48], the benefits of using a bicycle, basic mechanical checks, positions on the road, cyclist signalling and the order of priority of traffic signs, gear changes, advice on clothing, and weather, were presented. Subsequently, the second practical intervention was applied, which was carried out in a $15 \times 25 \mathrm{~m}$ sports field of the university, where a circuit was set up in order to reproduce the interactions of a situation of bicycle use in a real urban context, with the use of safety cones and traffic signs held by participants, who were located at intersections signalling "stop" or "give way". The purpose of this intervention experience was for the subjects to broaden their view of the environment, interacting with the signage, making gear changes and slowing down, respecting vertical signs, and interacting with other cyclists and cars. In the third intervention, an urban route was carried out, incorporating the participants of $G_{1}$ for 35 min to the circulation in a real urban context, using the streets around the university campus. Finally, a fourth intervention of a theoretical nature was applied, in which feedback was given on basic aspects of circulation and a general review of the mechanical aspects of the bicycle and road signs was performed.

\subsection{Statistical Analysis}

For the statistical analysis, the data obtained in the pre and post measurements for both groups were entered into a matrix prepared in Microsoft Excel software, and then transferred to the STATA statistical software [version 13], with which the descriptive and inferential statistics were obtained. Subsequently, in order to establish the existence of significant differences between the two measurements, a comparison of means was carried out using the Student's t-test for related samples, considering a significance level of $p \leq 0.05$. The above took into consideration that the distribution of the data in both measures was normal once the Shapiro-Wilk test was applied ( $p \geq 0.05)$. 


\section{Results}

In Table 2, we present the results obtained corresponding to the average and standard deviation (SD) of correct answers for each item of the questionnaire, before and after the intervention. The results for the intervention and control groups are shown in the corresponding columns.

Table 2. Total results per item of the instrument.

\begin{tabular}{|c|c|c|c|c|c|}
\hline & \multirow{3}{*}{ Items } & \multicolumn{2}{|c|}{$\mathrm{G}_{1}$} & \multicolumn{2}{|c|}{$\mathrm{G}_{2}$} \\
\hline & & Pre-Test & Post-Test & Pre-Test & Post-Test \\
\hline & & $\mathbf{M} \pm \mathbf{S D}$ & $\mathbf{M} \pm \mathbf{S D}$ & $\mathbf{M} \pm \mathbf{S D}$ & $\mathbf{M} \pm \mathbf{S D}$ \\
\hline & 1 & $0.98 \pm 0.13$ & $0.99 \pm 0.09$ & $0.98 \pm 0.15$ & $0.98 \pm 0.15$ \\
\hline & 2 & $0.01 \pm 0.09$ & $0.17 \pm 0.38$ & $0 \pm 0$ & $0 \pm 0$ \\
\hline & 3 & $1 \pm 0$ & $1 \pm 0$ & $1 \pm 0$ & $1 \pm 0$ \\
\hline & 4 & $0.97 \pm 0.18$ & $0.88 \pm 0.32$ & $0.95 \pm 0.22$ & $0.93 \pm 0.26$ \\
\hline & 5 & $0.28 \pm 0.45$ & $0.34 \pm 0.47$ & $0.17 \pm 0.38$ & $0.29 \pm 0.46$ \\
\hline Conceptual & 6 & $0.56 \pm 0.5$ & $0.62 \pm 0.49$ & $0.62 \pm 0.49$ & $0.52 \pm 0.5$ \\
\hline \multirow{11}{*}{ Dimension } & 7 & $0.91 \pm 0.29$ & $0.92 \pm 0.28$ & $0.90 \pm 0.3$ & $0.98 \pm 0.15$ \\
\hline & 8 & $1 \pm 0$ & $1 \pm 0$ & $1 \pm 0$ & $0.98 \pm 0.15$ \\
\hline & 9 & $0.73 \pm 0.45$ & $0.82 \pm 0.38$ & $0.78 \pm 0.42$ & $0.78 \pm 0.42$ \\
\hline & 10 & $0.36 \pm 0.48$ & $0.38 \pm 0.49$ & $0.52 \pm 0.5$ & $0.17 \pm 0.38$ \\
\hline & 11 & $0.97 \pm 0.15$ & $0.99 \pm 0.09$ & $0.93 \pm 0.26$ & $0.98 \pm 0.15$ \\
\hline & 12 & $0.33 \pm 0.47$ & $0.33 \pm 0.47$ & $0.43 \pm 0.5$ & $0.43 \pm 0.5$ \\
\hline & 13 & $0.61 \pm 0.49$ & $0.85 \pm 0.36$ & $0.58 \pm 0.5$ & $0.59 \pm 0.5$ \\
\hline & 14 & $0.81 \pm 0.39$ & $0.90 \pm 0.3$ & $0.90 \pm 0.3$ & $0.67 \pm 0.5$ \\
\hline & 15 & $0.81 \pm 0.39$ & $0.89 \pm 0.31$ & $0.93 \pm 0.26$ & $0.79 \pm 0.41$ \\
\hline & 16 & $0.45 \pm 0.5$ & $0.80 \pm 0.4$ & $0.41 \pm 0.5$ & $0.55 \pm 0.5$ \\
\hline & 17 & $0.91 \pm 0.29$ & $0.84 \pm 0.36$ & $0.85 \pm 0.36$ & $0.82 \pm 0.39$ \\
\hline Attitudinal & 18 & $0.93 \pm 0.25$ & $0.97 \pm 0.18$ & $0.97 \pm 0.16$ & $0.95 \pm 0.22$ \\
\hline \multirow[t]{7}{*}{ Dimension } & 19 & $0.97 \pm 0.16$ & $0.98 \pm 0.13$ & $0.95 \pm 0.21$ & $1 \pm 0$ \\
\hline & 20 & $0.55 \pm 0.5$ & $0.59 \pm 0.49$ & $0.48 \pm 0.5$ & $0.46 \pm 0.5$ \\
\hline & 21 & $0.98 \pm 0.13$ & $0.94 \pm 0.23$ & $1 \pm 0$ & $1 \pm 0$ \\
\hline & 22 & $0.92 \pm 0.26$ & $0.94 \pm 0.23$ & $1 \pm 0$ & $0.95 \pm 0.22$ \\
\hline & 23 & $0.82 \pm 0.38$ & $0.88 \pm 0.32$ & $0.81 \pm 0.4$ & $0.83 \pm 0.38$ \\
\hline & 24 & $0.95 \pm 0.21$ & $0.95 \pm 0.22$ & $0.95 \pm 0.22$ & $0.95 \pm 0.22$ \\
\hline & 25 & $0.81 \pm 0.39$ & $0.81 \pm 0.39$ & $0.79 \pm 0.41$ & $0.90 \pm 0.3$ \\
\hline
\end{tabular}

In relation to the conceptual dimension, according to the results, $G_{1}$ in the pre-test obtained a mean of 8.68 points $(\mathrm{SD}= \pm 1.2)$ with a minimum of 6 and a maximum of 11 points; while in the post-test, the mean was 9.22 points $(\mathrm{SD}= \pm 1.4)$ with a minimum of 4 and a maximum of 12 points. This indicates an improvement, with respect to the pre-test, of $6.2 \%$, with a $p$-value $=0.0009$. On the other hand, $\mathrm{G}_{2}$ in the pre-test obtained a mean of 8.79 points ( $\mathrm{SD}= \pm 1.4$ ) with a minimum of 4 and a maximum of 12 points; while in the post-test, the mean was 8.57 points $(\mathrm{SD}= \pm 1.3)$ with a minimum of 6 and a maximum of 11 points. This indicates a decrease of $2.5 \%$, with a $p$-value $=0.49$.

The results of the attitudinal dimension (cycling behaviour) showed that $G_{1}$ in the pre-test obtained a mean of 9.8 points $(\mathrm{SD}= \pm 1.4)$ with a minimum of 5 and a maximum of 12 points, while, in the post-test measurement, the mean was 10.43 points $(\mathrm{SD}= \pm 1.3)$ with a minimum of 7 and a maximum of 12 points. This shows a percentage improvement of $6.1 \%$, with a $p$-value $=0.0001$. As for the results obtained for $\mathrm{G}_{2}$, in the pre-test measurement, a mean of 9.86 points $(\mathrm{SD}= \pm 1.1)$ was obtained with a minimum of 7 and a maximum of 12 points. In the post-test, the mean was 9.62 points $(\mathrm{SD}= \pm 1.4)$ with a minimum of 5 and a maximum of 12 points. This evidences a percentage decrease of $3 \%$, with a $p$-value $=0.42$.

Finally, the results of both dimensions showed that $\mathrm{G}_{1}$ in the pre-test obtained a mean of 18.48 points $(\mathrm{SD}= \pm 1.8)$ with a minimum of 13 and a maximum of 22 points. On the other hand, the post-test mean was 19.65 points $(S D= \pm 2)$ with a minimum of 15 and a 
maximum of 24 points. A percentage improvement of $6.5 \%$, with a significance of $p=0.0000$ and $r=-0.3$ was evidenced. In the pre-test, $\mathrm{G}_{2}$ scored a mean of 18.64 points $(\mathrm{SD}= \pm 2.1)$ with a minimum of 12 and a maximum of 22 points. On the other hand, the post-test mean was 18.19 points $(\mathrm{SD}= \pm 2)$ with a minimum of 13 and a maximum of 22 points. A percentage decrease of $2.2 \%$, with a $p$-value $=0.35$ and $r=0.1$, was evidenced.

\section{Discussion}

The results obtained in $G_{1}$ show statistically significant differences in the instrument applied before and after the implementation of the intervention, both as a whole and in each dimension separately. On the other hand, the results of $G_{2}$ do not show significant improvements in any of the dimensions investigated, nor in the instrument as a whole. These results corroborate what has been found in the literature, which highlights the importance of educating about active travel and road safety, so that people use the bicycle as a means of transport with greater confidence, and thus reduce the fear of motor vehicles $[49,50]$. In this line, Cruz [51] declares that among the frequent barriers to not using the bicycle as a means of transport is fear due to lack of information. In Spain, for example, road safety education is one of the minimum teaching objectives for primary education, highlighting how important it is to learn both conceptual and practical skills in order to avoid road traffic accidents [52]. In addition to this, Moreno [53] coincides with the results obtained in the present study and highlights the importance of incorporating cycling contents in school education, in order to improve physical condition and health, as well as to increase the knowledge and skills of schoolchildren and make them feel safer when using this means of transport.

On the above and in the same vein, López [42] affirms that in order to avoid accidents involving cyclists, it is necessary that they are educated about the rules of the road, the responsible use of bicycles, and improve motor skills when using them, these being the contents addressed during the interventions to the university students who participated in this research. Also, Schlundt, Warren, and Miller [54] emphasise the need for road safety education for cyclists, asserting that when cyclists are injured, it is usually their own responsibility.

In addition to the above, it is worth noting the research carried out by Guell et al. [50], who found that the more confident they are in their skills and abilities as drivers, the less they perceive environmental barriers to avoid cycling in the city, and that experiencing a cycling education workshop in the urban environment gives urban cyclists more confidence. Chillón et al. [55], highlighted that in the university population, the greater the active commuting, the lower the perception of barriers.

Finally, Bernate et al. [56] corroborated the importance of teaching basic cycling, as they mention how important it is for each person to adjust the design of their bicycle to their own anthropometric measurements, as it is this detail that will determine their comfort, performance, and will help prevent possible injuries. By complying with the above, it is more likely that the person will want to maintain their movements in an active way, contributing to their well-being, since PA through the use of bicycles has the potential to greatly improve physical health and be a strong contribution to a sustainable lifestyle [57].

\section{Conclusions}

This study concludes that the intervention was an effective method for the promotion and increase of knowledge about road rules for cycling in an urban area in the sample of university students analysed. Together with the above, the significant differences found in the post-intervention measurement, compared to the pre-intervention measurement, allow us to support the development of strategies and lines of action in the university context, such as the implementation of courses with theoretical-practical sessions on road safety education and cycling. As a main suggestion, the implementation of practical courses of longer duration is proposed for a more detailed preparation, with the opportunity to add more trips to the streets, considering frequent journeys of the participants. This will have 
a greater impact on confidence and safety levels through increased knowledge put into practice.

\section{Limitations}

One of the main limitations of this study was the instrument used, whose objective was to measure traffic rules and cyclist behavior. Given the nature of this type of intervention and research, it is recommended for future experiences to apply practical tests that provide greater objectivity in relation to the measurement of the variables. On the other hand, the instrument used has limitations for other cultural contexts, so it would be advisable to advance it in an international questionnaire, which would allow a comparative analysis of different realities.

Another limitation of this study is related to the number of participants, so it would be of great interest and contribution to the scientific community to carry out studies similar to this one, increasing the number of subjects and homogeneous sizes for all groups (control and intervention).

Finally, future research related to cycling knowledge and behavior in the university population should focus on working with larger data sets, in addition to improving the method of analysis to confirm that the results of this experiment are repeatable and that the improvement is statistically significant, allowing a generalization of the results. Some useful suggestions for future research in the area could be the application of linear mixed models, such as random effects.

Author Contributions: Conceptualization: M.A.-B. and D.D.-B.; methodology: M.A.-B., D.D.-B., L.E.-O., J.G.-C., C.C.-R. and F.G.-R.; software: M.A.-B. and F.G.-R.; formal analysis: M.A.-B. and C.M.-C.; investigation: M.A.-B., D.D.-B., L.E.-O., J.G.-C., C.C.-R., C.M.-C. and F.G.-R.; data curation: D.D.-B. and C.M.-C.; writing-original draft preparation: D.D.-B., M.A.-B., F.G.-R. and D.D.-B.; writing-review and editing: D.D.-B., M.A.-B., F.G.-R. and C.M.-C.; visualization: M.A.-B., F.G.-R. and D.D.-B.; supervision: M.A.-B. and D.D.-B. All authors have read and agreed to the published version of the manuscript.

Funding: This research was funded by the Unidad de Mejoramiento de la Docencia Universitaria (UMDU) of the Pontificia Universidad Católica de Valparaíso, call for proposals 2018 funding number $10 / 2018$.

Informed Consent Statement: The study was conducted according to the guidelines of the Declaration of Helsinki. Ethical review and approval were waived for this study, due to has adhered to ethical practices that include, fundamentally, the informed consent of the participants and adherence to the guidelines for the practice of good publications, developed by the Publications Ethics Committee (COPE, 1997).

Data Availability Statement: Not applicable.

Conflicts of Interest: The authors declare no conflict of interest of the study.

\section{References}

1. Pfahl, M. The Environmental Awakening in Sport. Solut. J. 2013, 4, 67-76.

2. Trecroci, A.; Invernizzi, P.L.; Monacis, D.; Colella, D. Actual and perceived motor competence in relation to body mass index in primary school-aged children: A systematic review. Sustainability 2021, 13, 9994. [CrossRef]

3. Take Action for the Sustainable Development Goals-United Nations Sustainable Development. Available online: https: / / www.un.org/sustainabledevelopment/sustainable-development-goals/ (accessed on 30 April 2021).

4. McCullough, B.P.; Orr, M.; Watanabe, N.M. Measuring externalities: The imperative next step to sustainability assessment in sport. J. Sport Manag. 2019, 34, 393-402. [CrossRef]

5. Medina, I.; Petermann-Rocha, F.; Waddell, H.; Díaz-Martínez, X.; Matus-Castillo, C.; Cigarroa, I.; Concha-Cisternas, Y.; SalasBravo, C.; Martínez-Sanguinetti, M.A.; Celis-Morales, C.; et al. Association between different modes of travelling and adiposity in chilean population: Findings from the Chilean National Health Survey 2016-2017. Int. J. Environ. Res. Public Health 2020, 17, 3731. [CrossRef]

6. Petermann-Rocha, F.; Brown, R.E.; Diaz-Martínez, X.; Leiva, A.M.; Martinez, M.A.; Poblete-Valderrama, F.; Garri-do-Méndez, A.; Matus-Castillo, C.; Luarte-Rocha, C.; Salas-Bravo, C.; et al. Association of leisure time and occupational physical activity with obesity and cardiovascular risk factors in Chile. J. Sports Sci. 2019, 37, 2549-2559. [CrossRef] [PubMed] 
7. Garber, C.E.; Blissmer, B.; Deschenes, M.R.; Franklin, B.A.; Lamonte, M.J.; Lee, I.-M.; Nieman, D.C.; Swain, D.P.; American College of Sports Medicine American College of Sports Medicine Position Stand. Quantity and Quality of Exercise for Developing and Maintaining Cardiorespiratory, Musculoskeletal, and Neuromotor Fitness in Apparently Healthy Adults: Guidance for Prescribing Exercise. Med. Sci. Sports Exerc. 2011, 43, 1334-1359. [CrossRef]

8. Tudor-Locke, C.; Craig, C.L.; Brown, W.J.; Clemes, S.A.; De Cocker, K.; Giles-Corti, B.; Hatano, Y.; Inoue, S.; Matsudo, S.M.; Mutrie, N.; et al. How many steps/day are enough? For adults. Int. J. Behav. Nutr. Phys. Act. 2011, 8, 79. [CrossRef]

9. Bernardes, L.E.; da Silva, A.R.V.; Costa, J.V.; de Freitas, R.W.J.F.; Campos, K.B.A.C.; Deus, Z.L.C. de Prática de atividade física em adolescentes de escolas públicas: Um estudo descritivo. Online Braz. J. Nurs. 2013, 12, 209-217. [CrossRef]

10. Rico, C.D. Inactividad física y sedentarismo en la población española. Rev. Investig. Educ. Cienc. Salud (RIECS) 2017, 2, 41-48. [CrossRef]

11. Guthold, R.; Stevens, G.A.; Riley, L.M.; Bull, F.C. Worldwide trends in insufficient physical activity from 2001 to 2016 : A pooled analysis of 358 population-based surveys with 1.9 million participants. Lancet Glob. Health 2018, 6, e1077-e1086. [CrossRef]

12. The UN Decade of Education for Sustainable Development (DESD 2005-2014): The First Two Years; UNESCO: Paris, France, 2008 ; p. 64.

13. Carolee, B.; Heather, C. Shaping the Future We Want: UN Decade of Education for Sustainable Development; Final Report; UNESCO: Paris, France, 2014; ISBN 978-92-3-100053-9.

14. Yepes, J.G.M.; Díaz, Á.J.G. El deporte, otras vertientes y la diversidad de sus clasificaciones. Lúdica Pedagógica 2000, 4, 1-12. [CrossRef]

15. Almorza, D.; Prada-Olivera, J.A. Estudio diagnóstico del deporte universitario español. Ibero-Am. J. Exerc. Sports Psychol. 2019, 14, 89-90.

16. Van Mechelen, W.; Twisk, J.W.R.; Post, G.B.; Snel, J.; Kemper, H.C.G. Physical activity of young people: The amsterdam longitudinal growth and health study. Med. Sci. Sports Exerc. 2000, 32, 1610-1616. [CrossRef]

17. Wengreen, H.J.; Moncur, C. Change in diet, physical activity, and body weight among young-adults during the transition from high school to college. Nutr. J. 2009, 8, 32. [CrossRef]

18. Forman, H.; Kerr, J.; Norman, G.J.; Saelens, B.E.; Durant, N.H.; Harris, S.K.; Sallis, J.F. Reliability and validity of destination-specific barriers to walking and cycling for youth. Prev. Med. 2008, 46, 311-316. [CrossRef]

19. García-Hermoso, A.; Quintero, A.P.; Hernández, E.; Correa-Bautista, J.E.; Izquierdo, M.; Tordecilla-Sanders, A.; Prieto-Benavides, D.; Sandoval-Cuellar, C.; González-Ruíz, K.; Villa-González, E.; et al. Active commuting to and from university, obesity and metabolic syndrome among colombian university students. BMC Public Health 2018, 18, 523. [CrossRef]

20. Melero, I.M.; Gil, F.J.M. La Utilización de la bicicleta entre el alumnado universitario. Wanceulen Educ. Física Digit. $2011,8,1$.

21. Velázquez Monroy, Ó.; Barinagarrementería Aldatz, F.S.; Rubio Guerra, A.F.; Verdejo, J.; Méndez Bello, M.Á.; Violante, R.; Pavía, A.; Alvarado-Ruiz, R.; Lara Esqueda, A. Morbilidad y mortalidad de la enfermedad isquémica del corazón y cerebrovascular en México. 2005. Arch. Cardiol. México 2007, 77, 31-39.

22. UANL Entorno Universitario. Available online: https://www.uanl.mx/publicaciones-revista-entorno-universitario (accessed on 22 August 2021).

23. Garcia, M.P.; Gutierrez, S.H.; Ruiz, J.R.; Garzón, P.C. Fiabilidad de un cuestionario de barreras del desplazamiento activo al colegio (Reliability of a questionnaire on barriers to active transportation to school). Retos 2017, 32, 72-75. [CrossRef]

24. Agarwal, A. Quantifying health \& economic benefits of bicycle superhighway: Evidence from Patna. Procedia Comput. Sci. 2021, 184, 692-697. [CrossRef]

25. Jakovcevic, A.; Franco, P.; Dalla Pozza, M.V.; Ledesma, R. Percepción de los beneficios individuales del uso de la bicicleta compartida como modo de transporte. Suma Psicológica 2016, 23, 33-41. [CrossRef]

26. El Boom del Ciclismo Urbano: El Rol del Desarrollo Urbano y Las Políticas Públicas. Available online: https:/ / estudiosurbanos uc.cl/exalumnos/el-boom-del-ciclismo-urbano-el-papel-del-desarrollo-urbano-y-las-politicas-publicas/ (accessed on 22 August 2021).

27. Troncoso, L.D.M.; Manfiolete, S.S.T.R.D.; Toro-Arévalo, S.A. Procesos educativos vivenciados en la práctica social mecánica de bicicleta (Educational processes experienced in the social mechanical bicycle practice). Retos 2020, 38, 102-108. [CrossRef]

28. Sallis, J.F.; Cervero, R.B.; Ascher, W.; Henderson, K.A.; Kraft, M.K.; Kerr, J. An ecological approach to creating active living communities. Annu. Rev. Public Health 2006, 27, 297-322. [CrossRef]

29. González, E.V.; Rodríguez-López, C.; Delgado, F.J.H.; Tercedor, P.; Ruiz, J.R.; Chillón, P. Factores personales y ambientales asociados con el desplazamiento activo al colegio de escolares españoles. Rev. Psicol. Deporte 2012, 21, 343-349.

30. Molina-García, J.; Queralt, A.; Estevan, I.; Álvarez, O.; Castillo, I. Barreras percibidas en el desplazamiento activo al centro educativo: Fiabilidad y validez de una escala. Gac. Sanit. 2016, 30, 426-431. [CrossRef] [PubMed]

31. Pucher, J.; Buehler, R. Cycling towards a more sustainable transport future. Transp. Rev. 2017, 37, 689-694. [CrossRef]

32. De Carvalho, M.L.; de Freitas, C.M. Cycling to achieve healthy and sustainable alternatives. Cien. Saude Colect. 2012, 17, 1617-1628. [CrossRef]

33. Encuesta Nacional de Salud. Available online: http://www.encuestas.uc.cl/ens/index.html (accessed on 22 August 2021).

34. Albala, C.; Olivares, S.; Salinas, J.; Vio, F. (Eds.) Bases, prioridades y desafíos de la promoción de la salud. Rev. Chil. Nutr. 2004, 31, 183. [CrossRef]

35. Olivares, C.S.; Lera, M.L.; Bustos, Z.N. Etapas del cambio, beneficios y barreras en actividad física y consumo de frutas y verduras en estudiantes universitarios de Santiago de Chile. Rev. Chil. Nutr. 2008, 35, 25-35. [CrossRef] 
36. Blasco, T.; Capdevila Ortís, L.; Pintanel i Bassets, M.; Valiente Barros, L.; Cruz Feliu, J. Evolución de los patrones de actividad física en estudiantes universitarios. Rev. Psicol. Deporte 1996, 5, 0051-0063.

37. Espinoza, O.L.; Rodríguez, R.F.; Gálvez, C.J.; MacMillan, K.N. Hábitos de alimentación y actividad física en estudiantes universitarios. Rev. Chil. Nutr. 2011, 38, 458-465. [CrossRef]

38. Rodríguez Rodríguez, F.J.; Espinoza Oteiza, L.R.; Gálvez Carvajal, J.; Macmillan Kuthe, N.G.; Solis Urra, P. Estado nutricional y estilos de vida en estudiantes universitarios de la Pontificia Universidad Católica de Valparaíso. Univ. Salud 2013, 15, 123-135.

39. Boye, M.A.; Duclos-Bastías, D.; Oteiza, L.E.; Ramírez, F.G. Implementación de un programa de ciclismo urbano en estudiantes universitarios chilenos (Implementation of an urban bicycling programme in Chilean university students). Retos 2021, 41, 328-334. [CrossRef]

40. Osorio, A. El Transporte Activo en la Comunidad Universitaria. Conocimientos, Barreras y Usos de la Bicicleta en la Universidad Tecnológica de Pereira 2015. Ph.D. Thesis, Universidad Tecnológica de Pereira, Facultad de Ciencias de la Salud, Pereira, Colombia, 2016.

41. Castillo-Paredes, A.; Inostroza Jiménez, N.; Parra-Saldías, M.; Palma-Leal, X.; Felipe, J.L.; Págola Aldazabal, I.; Díaz-Martínez, X.; Rodríguez-Rodríguez, F. Environmental and psychosocial barriers affect the active commuting to university in chilean students. Int. J. Environ. Res. Public Health 2021, 18, 1818. [CrossRef]

42. López Pérez, J.F. Muévete con Bici: Un Proyecto Sducativo; Universidad de Granada: Granada, Spain, 2017.

43. Argibay, J. Técnicas psicométricas. cuestiones de validez y confiabilidad. Subj. Procesos Cogn. 2006, 8, 15-33.

44. Galicia Alarcón, L.A.; Balderrama Trápaga, J.A.; Edel Navarro, R. Validez de contenido por juicio de expertos: Propuesta de una herramienta virtual. Apertura. 2017, 9, 42-53. [CrossRef]

45. Ortiz-Gutiérrez, S.; Cruz-Avelar, A. Translation and cross-cultural adaptation of health assessment tools. Actas Dermo Sifiliogr. 2018, 109, 202-206. [CrossRef]

46. Manual Prospectiva Universidad Deusto [PDF] I Free PDF Manuals. Available online: https://dl-manual.com/doc/manualprospectiva-universidad-deusto-mnop1ynd6koq (accessed on 22 August 2021).

47. Nuntius, S. Singapore Statement on Research Integrity. Available online: https://wcrif.org/guidance/singapore-statement (accessed on 22 August 2021).

48. Nacional, B. del C. Biblioteca Del Congreso Nacional । Ley Chile. Available online: https://www.bcn.cl/leychile (accessed on 1 September 2021).

49. Molina-García, J.; Castillo, I.; Sallis, J.F. Psychosocial and Environmental Correlates of Active Commuting for University Students. Prev. Med. 2010, 51, 136-138. [CrossRef]

50. Guell, C.; Panter, J.; Ogilvie, D. Walking and Cycling to Work despite Reporting an Unsupportive Environment: Insights from a Mixed-Method Exploration of Counterintuitive Findings. BMC Public Health 2013, 13, 497. [CrossRef]

51. Cruz, C. Efectos de la Aplicación de un Programa de Entrenamiento de Ciclismo Urbano en Estudiantes Universitarios de la Pontificia Universidad Católica de Valparaíso; Pontificia Universidad Católica de Valparaíso: Valparaíso, Chile, 2016.

52. Aula En Bici: Un Proyecto Longitudinal de Intervención Docente En Ed. Primaria (Class by Bicycle: A Longitudinal Project of Educational Intervention in Primary School) I Retos. Available online: https://recyt.fecyt.es/index.php/retos/article/view/34 558 (accessed on 22 August 2021).

53. Bello Ángel, L.F.; Cortes Moreno, J.A.; Rodríguez Castro, M.A.; Rojas Vega, A. El Uso Formativo de la Bicicleta Para el Fortalecimiento de los Valores, en Escolares del Contexto Rural. Diploma Thesis, Universidad Pedagógica Nacional, Bogotá, Colombia, 2019.

54. Schlundt, D.; Warren, R.; Miller, S. Reducing unintentional injuries on the nation's highways: A literature review. J. Health Care Poor Underserved 2004, 15, 76-98. [CrossRef]

55. Chillón, P.; Martínez-Gómez, D.; Ortega, F.B.; Pérez-López, I.J.; Díaz, L.E.; Veses, A.M.; Veiga, O.L.; Marcos, A.; DelgadoFernández, M. Six-year trend in active commuting to school in Spanish adolescents. Int. J. Behav. Med. 2013, 20, 529-537. [CrossRef] [PubMed]

56. Bernate, J.A.; Cruz, L.; Betancourt, M.; Fonseca, I.; Arias, C.; Gómez, K. Bike fitting para el rendimiento y la prevención de lesiones en ciclistas de ruta aficionados y profesionales. VIREF Rev. Educ. Física 2020, 9, 63-71.

57. Buehler, R.; Pucher, J.; Bauman, A. Physical Activity from walking and cycling for daily travel in the United States, 2001-2017: Demographic, socioeconomic, and geographic variation. J. Transp. Health 2020, 16, 100811. [CrossRef] 